\title{
Application of LEAP model on long-term electricity demand forecasting in Indonesia, period 2010-2025
}

\author{
Jaka Windarta ${ }^{1,3}$, Bambang Purwanggono ${ }^{2}$, and Fuad Hidayanto ${ }^{1, *}$ \\ ${ }^{1}$ Master Program of Energy, Diponegoro University, Semarang, Indonesia \\ ${ }^{2}$ Department of Industrial Engineering, Diponegoro University, Semarang, Indonesia \\ ${ }^{3}$ Department of Electrical Engineering, Diponegoro University, Semarang, Indonesia
}

\begin{abstract}
Electricity demand forecasting is an important part in energy management especially in electricity planning. Indonesia is a large country with a pattern of electricity consumption which continues to increase, therefor need to forecasting electricity demand in order to avoid unbalance demand and supply or deficit energy. LEAP (Long-range Energy Alternative Planning System) as a tool energy model and Indonesia as a case study. Basically, electricity demand is influenced by population, economy and electricity intensity. The purpose of this study is to provide understanding and application of electricity demand forecasting by using LEAP. The base year is 2010 and end year projection is 2025. The scenarios of simulated model consist of two scenarios. They are Business as Usual (BAU) and Government policy scenario. Results of both scenarios indicate that end year electricity demand forecasting in Indonesia increased more than two fold compared to base year.

Keywords: electricity, demand forecasting, LEAP, scenario, Indonesia.
\end{abstract}

\section{Introduction}

Energy has an important role in human life since ancient times. Animals were used to plow rice fields, firewood for cooking and the use of wind for sailing is proof that energy is important in supporting human life [1]. Energy sources, in terms of usage, consist of primary energy and secondary energy. Primary energy is the energy given by nature directly without processing. While secondary energy is the primary energy that has further process. Petroleum, natural gas and coal are forms of primary energy. Electricity is one form of secondary energy. Based on the type of fuel, electricity is the most widely used energy after petroleum [2]. In addition, electricity is easily to trasmitted through transmission and distribution line, easy to use and a lot of devices on the world need electricity as power source.

Indonesia is the fourth most populous nation in the world. The archipelago approximately 17,508 islands located between latitude $6^{\circ}$ North and $11^{\circ}$ South and longitude $95^{\circ}$ East and $141^{\circ}$ East [3]. As reported in the 2010 census conducted by Statistics

*Corresponding email: fuad.hidayanto@yahoo.com 
Indonesia (Badan Pusat Statistik, BPS), the population of Indonesia was 237.5 million with population growth of $1.37 \%$. GDP growth per annum from 2010 to 2015 average increase of $5.72 \%$ and reach highest value of $6.5 \%$ [4]. GDP growth in 2015 decreased only $4.57 \%$, it is due to global economy not stable affecting demand of Indonesia's export product. There is a relationship between economic growth and electricity consumption in Indonesia [5].

The share of electricity consumption is $18.2 \%$ of the national energy consumption in 2015 [4]. Electricity demand in the future will increase along the increasing number of electrical equipment products. For example electric stoves, electric bikes and electric cars have began to be developed. Electrical equipment is considered more environmentally friendly than existing equipment with fuel oil and gas that may cause air pollution. The increasing growth of electricity demand need to be anticipated with the provision of power plants. In the electricity management need planning of electricity demand and supply of power plants.

Base on the reveal above, electricity demand forecasting in future is important in order to avoid unbalance demand and supply or deficit energy. Several methods have been developed such as the markov model, fuzi linear regression and a combination of existing methods [2]. Factors or variables that affect electricity demand include population, gross domestic product (GDP), electrification ratio and other intensity.

\section{Literature Review}

Electricity supply in Indonesia shall be under the control of the state, which supplies shall be provided by the government and the regional government under the principle or regional autonomy. The implementation of electricity supply business is carried out by state-owned enterprises (BUMN), regional-owned enterprises (BUMD), private enterprises, cooperatives and self-supporting communities [6]. Every power supply entrepreneur is obliged to hold a business license for electricity supply (IUPTL). PLN is one of the holders of IUPTL which business area covers the entire territory of the Republic of Indonesia as figure 1 .

In 2015, the installed capacity of power plants in Indonesia reaches 55.5 thousand MW consisting of PLN power plants amounting to 38.3 thousand MW and non PLN of 17.2 thousand MW [7]. Compared to 2014 the installed capacity of power plants has been risen by $4.64 \%$. The supply of electricity amounted to $233,981.98 \mathrm{GWh}$ which consists of PLN's electricity production of $176,472.21 \mathrm{GWh}$ and purchases of 57,509.77 GWh. Electricity consumption in 2015 amounted to $202,845.82 \mathrm{GWh}$, an increase of $2.13 \%$ from the previous year. Table 1 present the electricity consumption in Indonesia.

PLN customers consist four main sectors. They are household customers, industrial customers, business customers and public customers. The number of customers in year 2015 reached $61,167,980$ customers increasing of $6.39 \%$ over the previous year [8]. From the total number of customers, the household group is the largest number of customers, $56,605,260$ customers or $92.54 \%$. The electrification ratio is the ratio of the electrified household to the number of households. Electrification ratio in 2015 reached $88.30 \%$ or increased 3.94\% from the previous year [7]. 


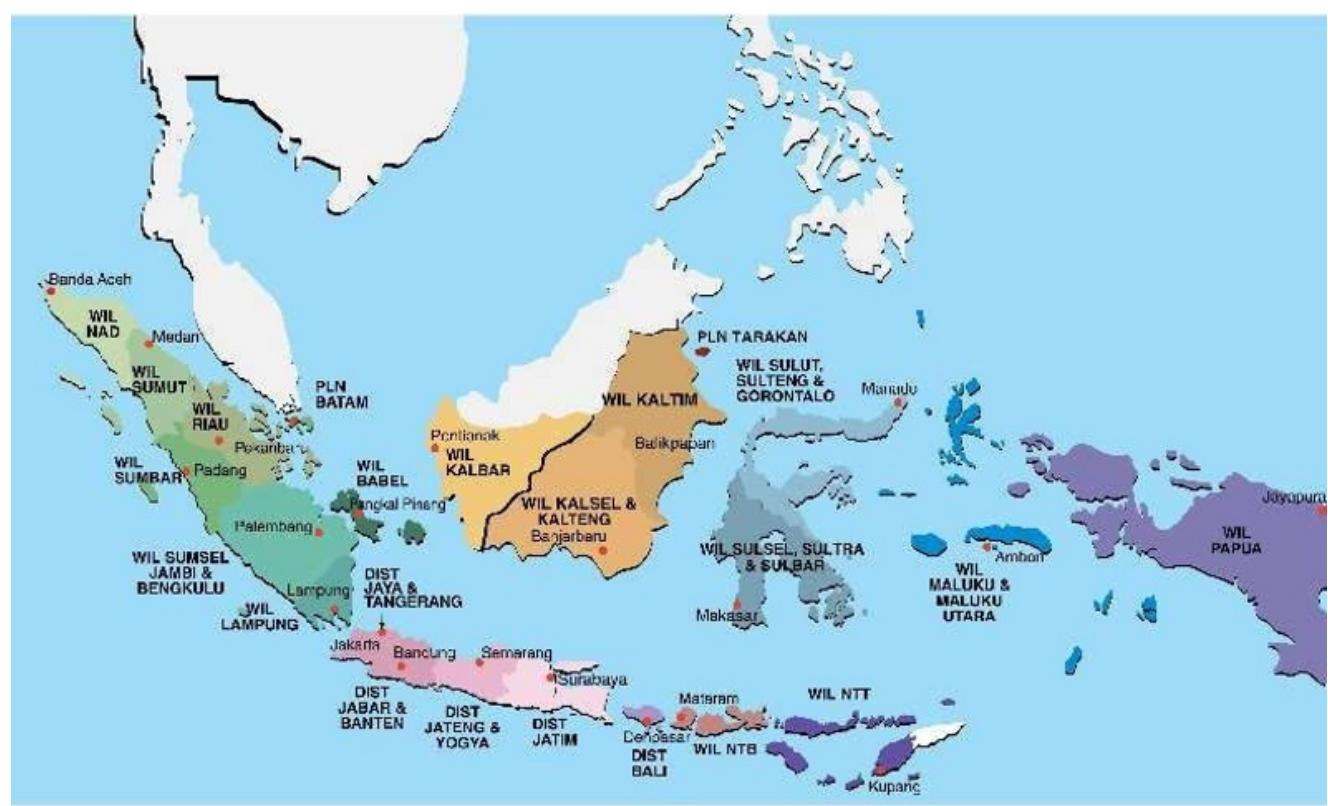

Fig. 1. Map of Business Area PLN [9]

Table 1. Electricity Consumption in Indonesia [8]

\begin{tabular}{|l|r|r|r|r|r|r|}
\hline \multirow{2}{*}{ Sector } & \multicolumn{7}{|c|}{ Electricity Consumption (GWh) } \\
\cline { 2 - 7 } & $\mathbf{2 0 1 0}$ & $\mathbf{2 0 1 1}$ & $\mathbf{2 0 1 2}$ & $\mathbf{2 0 1 3}$ & $\mathbf{2 0 1 4}$ & $\mathbf{2 0 1 5}$ \\
\hline Household & $59.824,94$ & $65.111,57$ & $72.132,54$ & $77.210,71$ & $84.086,46$ & $88.682,13$ \\
\hline Industry & $50.985,20$ & $54.725,82$ & $60.175,96$ & $64.381,40$ & $65.908,68$ & $64.079,39$ \\
\hline Business & $27.157,22$ & $28.307,21$ & $30.988,64$ & $34.498,38$ & $36.282,42$ & $36.978,05$ \\
\hline Public & $9.330,11$ & $9.848,06$ & $10.693,60$ & $11.450,53$ & $12.324,21$ & $13.116,25$ \\
\hline Total & $147.297,47$ & $157.992,66$ & $173.990,74$ & $187.541,02$ & $198.601,77$ & $202.855,82$ \\
\hline
\end{tabular}

\section{The Mothodology of Research}

\subsection{LEAP Model}

The LEAP (Long-range Energy Alternative Planning System) model is a static energy economicy - environment model developed by the Stockholm Environment Institute in Boston, USA since 1980 [10]. LEAP has been used by more than 190 countries in the world [2]. The Leap model can be used to calculate energy requirements, transformations and energy sources.

The modeling methodology in LEAP is accounting. Energy demand or energy supply is calculated by summing up the energy consumption and supply of each type of activity. Leap provides four main modules used in energy modeling. They are key assumptions, demand, transformation, and resources [11]. Key assumptions module consists of data such as population size, population growth, nominal GDP (Gross Domestic Product), GDP growth, number of household customers and other parameters. Demand module consists of four sectors, they are household, industry, business and public. 


\subsection{Final electricity demand analysis}

Final electricity demand analysis is calculated for each year and branch (sector). Electricity demand is calculated as a product of total activity and electrical intensity [2].

$$
\mathrm{ED}_{\mathrm{b}, \mathrm{s}, \mathrm{t}}=\mathrm{TA}_{\mathrm{b}, \mathrm{s}, \mathrm{t}} \cdot \mathrm{EI}_{\mathrm{b}, \mathrm{s}, \mathrm{t}}
$$

Where ED is electricity demand, TA is total activity, EI is electricity intensity, $\mathrm{b}$ is sector, $\mathrm{s}$ is scenario and $\mathrm{t}$ is time (year). In the final electricity demand analysis, energy intensity can be calculated from electricity consumption and the number of customer [2]. It can also be energy intensity defined as the total amount of energy consumption per unit of gross domestic product (GDP) [12]. The number of customer and GDP is referred to as total activity.

$$
E I_{b, t}=\frac{E C_{b, t}}{T_{b}, t}
$$

or

$$
\mathrm{EI}_{\mathrm{b}, \mathrm{t}}=\frac{\mathrm{EC}_{\mathrm{b}, \mathrm{t}}}{\mathrm{GDP}_{\mathrm{b}, \mathrm{t}}}
$$

Where EI is electricity intensity, EC is electricity consumption, TC is total customer number, GDP is gross domestic product, $\mathrm{b}$ is sector and $\mathrm{t}$ is time (year).

\subsection{Forecasting method}

The electricity demand forecasting in this study is calculated by a very simple model. For household sector, the electricity demand is calculated from the number of household customers and its electricity intensity. Projected number of household customers based on population growth, household size (family member) and electrification ratio.

$$
\mathrm{TC}_{\mathrm{h}, \mathrm{s}, \mathrm{t}}=\frac{\mathrm{P}_{\mathrm{s}, \mathrm{t}}}{H_{\mathrm{s}, \mathrm{t}}} \cdot \mathrm{ER}_{\mathrm{s}, \mathrm{t}}
$$

Where $\mathrm{TC}_{\mathrm{h}}$ is total customer of household sector, $\mathrm{P}$ is number of population, $\mathrm{H}_{\mathrm{S}}$ is average of household member (household size) and ER is the electrification ratio. The number of households is calculated from the division of number population with household size. Electrification ratio is ratio of number of households with electricity divided by number of households throughout Indonesia or the percentage of households with electricity [12].

$$
\mathrm{ED}_{\mathrm{h}, \mathrm{s}, \mathrm{t}}=\frac{\mathrm{P}_{\mathrm{s}, \mathrm{t}}}{H_{\mathrm{s}, \mathrm{t}}} \cdot \mathrm{ER}_{\mathrm{s}, \mathrm{t}} \cdot \mathrm{EI}_{\mathrm{h}, \mathrm{s}, \mathrm{t}}
$$

Where ED is electricity demand in household sector, EI is the electricity intensity in household sector, P, HS and ER, s, t are as defined above. So the electricity demand forecasting for household sector can be calculated by projecting population, household size, electrification ratio and electricity intensity [2].

Electricity demand for non-household sector is calculated simpler than household sector. There are only two factors used in this method. They are gross domestic product and electricity intensity.

$$
\mathrm{ED}_{\mathrm{i}, \mathrm{s}, \mathrm{t}}=\mathrm{PDB}_{\mathrm{i}, \mathrm{s}, \mathrm{t}} \cdot \mathrm{EI}_{\mathrm{i}, \mathrm{s}, \mathrm{t}}
$$




$$
\begin{aligned}
& \mathrm{ED}_{\mathrm{b}, \mathrm{s}, \mathrm{t}}=\mathrm{PDB}_{\mathrm{b}, \mathrm{s}, \mathrm{t}} \cdot \mathrm{EI}_{b, \mathrm{~s}, \mathrm{t}} \\
& \mathrm{ED}_{p, \mathrm{~s}, \mathrm{t}}=\mathrm{PDB}_{\mathrm{p}, \mathrm{s}, \mathrm{t}} \cdot \mathrm{EI}_{p, \mathrm{~s}, \mathrm{t}}
\end{aligned}
$$

Where ED is electricity demand while $\mathrm{i}, \mathrm{b}$ dan $\mathrm{p}$ describe branch or sector, business and public.

\subsection{Scenario Developments}

In this study, the base year of the leap model is set from 2010-2015. The fist year scenario start in 2016 and ends in 2025. The population, household size (family member) and GDP at constant price 2000 from $2010-2015$ as Table 2 . The electrification ratio is set at $100 \%$ by 2020 according to Government targets [12][13].

Household electrical intensity used average value from 2010 to 2015 which is 1,549 $\mathrm{kWh}$ per household customer. In the non-household sector, energy intensity for each industry, business and public sectors was $22.36,12.02$ and $4.16 \mathrm{kWh}$ per million rupiah, respectively.

Table 2. Population, Household size and GDP [4]

\begin{tabular}{|c|c|c|c|c|c|c|}
\hline \multirow{2}{*}{ Indication } & \multicolumn{7}{|c|}{ Year } \\
\cline { 2 - 7 } & $\mathbf{2 0 1 0}$ & $\mathbf{2 0 1 1}$ & $\mathbf{2 0 1 2}$ & $\mathbf{2 0 1 3}$ & $\mathbf{2 0 1 4}$ & $\mathbf{2 0 1 5}$ \\
\hline Population (Thousand People) & 237.641 & 238.519 & 245.425 & 248.818 & 252.165 & 255.462 \\
\hline Household size & 3,89 & 3,84 & 3,89 & 3,89 & 3,89 & 3,90 \\
\hline $\begin{array}{c}\text { GDP at Constant Price 2000 } \\
\text { (Trillion Rupiahs) }\end{array}$ & 2.314 & 2.465 & 2.618 & 2.770 & 2.909 & 3.042 \\
\hline
\end{tabular}

Two scenarios will be simulated in this study. They are Business as usual (BAU) scenario dan Government policy scenario. BAU scenario used trend data reference from year 2010-2015. Government policy scenario is influenced government policy such as BPS and RPJMN data.

\subsubsection{Business as Usual (BAU) scenario}

In BAU scenario the population growth projection uses the average value of population growth from $2010-2015$ is $1.44 \%$. Household size using the average value of household size from 2010-2015 is 3.9. Projected economic growth using the average GDP growth from 2010-2015 amounted to $5.72 \%$.

\subsubsection{Government policy scenario}

In government policy scenario the population growth projection uses the Indonesia population projection data 2010-2035 [14]. For the period of 2010-2015 the population growth projection is $1,19 \%$ and for the period of $2020-2025$ is $1,00 \%$. Projection of economic growth in 2015-2019 adopted economic growth rate in RPJMN year 2015-2019 issued by Bappenas that is equal to 7,1\%. For the period of 2020-2025, the economic projection uses the projected number of BPPT, which is an average of $6.4 \%$ per year [9]. 


\section{Results and Discussion}

Electricity demand forecasting for the BAU scenario and the Government's policy scenario are shown as in table 3 and table 4, respectively. In both scenarios, at the end of the scenario there is an increase of more than double the electricity requirement of the base year. In the 2025 BAU scenario, electricity needs to be $322.0 \mathrm{GWh}$ or an increase of 174.7 GWh from 2010. In the Government's policy scenario, electricity demand in 2025 is higher at 337.1 GWh or an increase of $189.9 \mathrm{GWh}$ from 2010.

In the household sector the BAU scenario of electricity demand projection is higher than the Government scenario. This is because the population growth BAU scenario is higher, probably due to Indonesian culture that states many children a lot of fortune. In the industrial sector, business and public BAU scenarios of projected electricity demand are lower than the Government scenario. This is because the economic growth as input reference scenario of BAU is the year 2010-2015 is still low due to global economy not stable.

Overall projection of BAU scenario electricity requirement is lower than Government policy scenario as shown in Figure 2. It is because of the optimism of the Government in increasing economic growth.

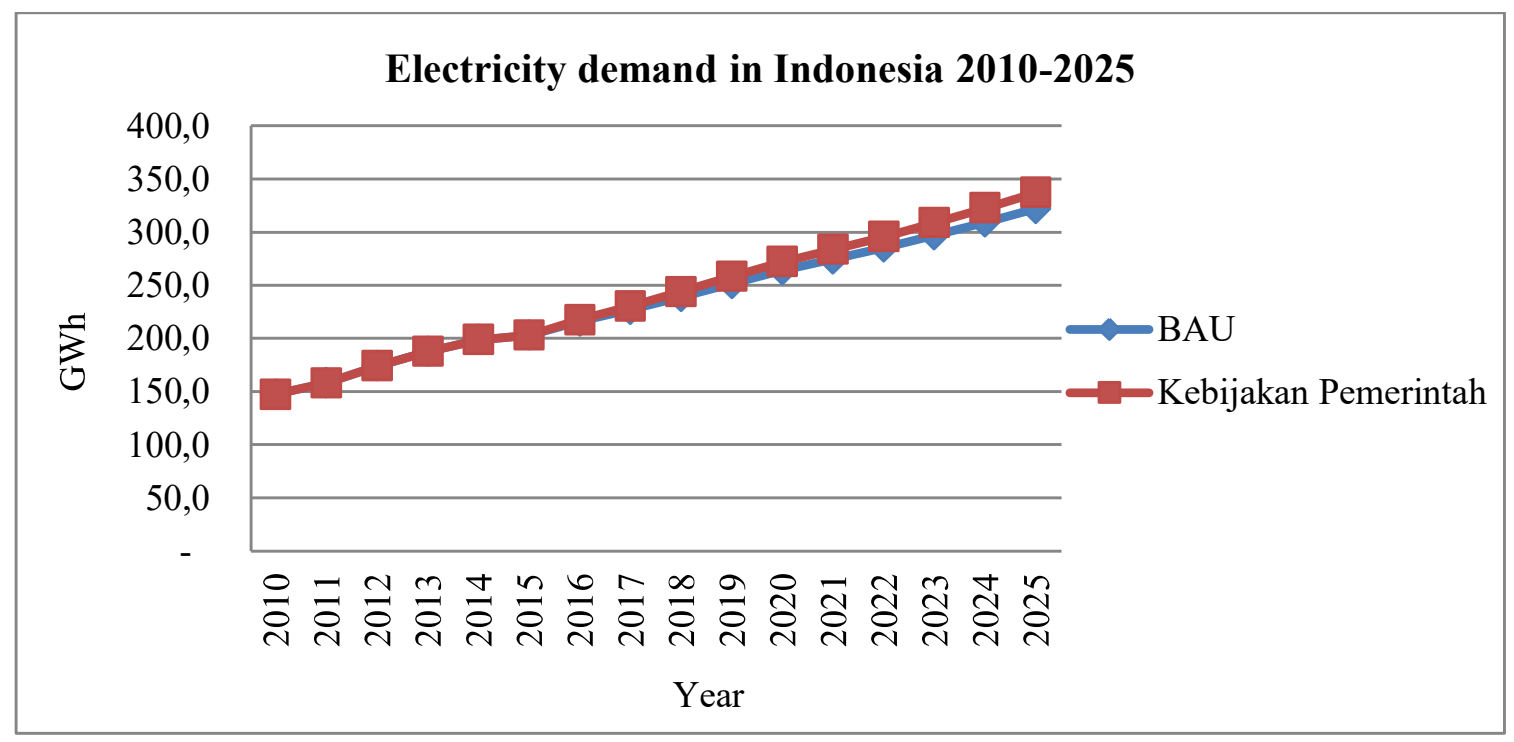

Fig. 2. Electricity demand in Indonesia 2010-2025

Table 3. Electricity Demand in Indonesia 2010-2025, Scenario BAU

\begin{tabular}{|c|c|c|c|c|}
\hline \multirow{2}{*}{ Sector } & \multicolumn{4}{|c|}{ Electricity demand (GWh) } \\
\cline { 2 - 5 } & $\mathbf{2 0 1 0}$ & $\mathbf{2 0 1 5}$ & $\mathbf{2 0 2 0}$ & $\mathbf{2 0 2 5}$ \\
\hline Household & 59,8 & 88,7 & 109,5 & 117,7 \\
\hline Industry & 51,0 & 64,1 & 89,8 & 118,6 \\
\hline Business & 27,2 & 37,0 & 48,3 & 63,8 \\
\hline Public & 9,3 & 13,1 & 16,6 & 21,9 \\
\hline Total & 147,3 & 202,9 & 264,3 & 322,0 \\
\hline
\end{tabular}


Table 4. Electricity Demand in Indonesia 2010-2025, Scenario Government Policy

\begin{tabular}{|c|c|c|c|c|}
\hline \multirow{2}{*}{ Sector } & \multicolumn{4}{|c|}{ Electricity demand (GWh) } \\
\cline { 2 - 5 } & $\mathbf{2 0 1 0}$ & $\mathbf{2 0 1 5}$ & $\mathbf{2 0 2 0}$ & $\mathbf{2 0 2 5}$ \\
\hline Household & 59,8 & 88,7 & 108,0 & 113,5 \\
\hline Industry & 51,0 & 64,1 & 95,2 & 129,8 \\
\hline Business & 27,2 & 37,0 & 51,2 & 69,8 \\
\hline Public & 9,3 & 13,1 & 17,6 & 24,0 \\
\hline Total & 147,3 & 202,9 & 272,0 & 337,1 \\
\hline
\end{tabular}

\section{Conclusion}

By the increasing of the population and economy every year, influence of increasing the amount of electricity consumption in Indonesia. Without anticipating the provision of proper power generation capacity can cause serious problems such as shortage of power supply. Therefore, the projection of electrical demand becomes important in planning the addition of generating capacity in the future. This study analyzes electricity demand forecasting from 2010-2025. Factors used in this projection are population, household size, electrification ratio, number of household customers, GDP and electricity intensity. The electricity demand forecasting is calculated by a simple mathematical model based on the value of the input variable. Simulated scenarios are two BAU scenarios and Government policy scenarios. BAU scenarios of data inputs use data averages of 2010-2015 while government policy scenarios use government targeted values such as BPS and RPJMN data. The results show an increase in electricity demand more than two fold by 2025 when compared to 2010. The projection of electricity demand for government policy scenarios is higher than the BAU scenario. This is because Government policy scenario optimism in improving economic growth, while BAU scenario in the year 2010-2015 as the reference year of a slowdown in the national economy due to the global economic crisis.

\section{Recommendation}

This study calculates only the projection of electricity demand, while for additional capacity of the electricity power plants has not been discussed. Therefore, further research on the readiness of electricity power plants is needed to evaluate their capacity to meet the growing demand for electricity in the future.

\section{References}

1. P. Yosgiantoro, Energy Economy. Theory and Practice, Pusaka LP3ES Indonesia, Jakarta (2000)

2. Suhono and Sarjiya, Long-Term Electricity Demand Forecasting Of Sumatera System Based On Electricity Consumption Intensity And Indonesia Population Projection 2010-2035, Energy Procedia 68, 455-462 (2015)

3. H. Batih and C. Sorapipatana, Characteristics of urban households' electrical energy consumption in Indonesia and its saving potentials, Renewable and Sustainable Energy Reviews 57, 1160-1173 (2016).

4. Pusdatin ESDM, Handbook of Energy \& Economic Statistics of Indonesia, (2016) 
5. T.D. Hartono and M. Kuncoro, Electricity consumption and economic growth: A Causality Evidence from Six Economic Corridors of Indonesia, Kuala Lumpur International Business, Economics, and Low Conference KLIBEL, 1984-2010 (2013)

6. Government of Republic of Indonesia, Law of the Republic of Indonesia number 30 Year 2009 Concerning Electricity, (2009)

7. Directorate General of Electricity, Ministry of Energy and Mineral Resourses, Electricity Statistics 2016, Jakatra, (2016)

8. $\quad$ PT PLN, PLNs Statistics 2015, (2015)

9. $\quad$ PT PLN, RUPTL PT PLN (Persero) Tahun 2016-2025, (2016)

10. T.O. Winarno, LEAP Energy Planning Guide. Center for Energy Policy Studies. Institut teknologi Bandung, (2006)

11. U. Perwez, A. Sohail, S.F. Hassan and U. Zia, The Long-Term Forecast of Pakistan's Electricity Supply And Demand: An Application of Long Range Energy Alternatives Planning. Energy 93, 2423-2435 (2015)

12. Government of Republic of Indonesia, Government Regulation of Republic of Indonesia No. 79 Year 2014 regrading National Energy Policy, (2014)

13. DEN, Indonesia Energy Outlook, Jakarta (2016)

14. Statistics Indonesia (BPS), Indonesia Population Projection 2010-2035, (2013) 